\title{
Hydrocarbon reservoir characterization of "Otan-lle" field, Niger Delta
}

\author{
Tokunbo Sanmi Fagbemigun ${ }^{1}$ [ - Michael Ayu Ayuk ${ }^{2}$. Olufemi Enitan Oyanameh ${ }^{3}$. Opeyemi Joshua Akinrinade ${ }^{4}$. \\ Joel Olayide Amosun ${ }^{1}$. Oluseun Adetola Sanuade ${ }^{5}$. Olaide Sakiru Hammed ${ }^{6}$. Ajibola Rashidat Oyebamiji ${ }^{7}$
}

Received: 5 February 2020 / Accepted: 12 December 2020 / Published online: 11 January 2021

(c) The Author(s) 2021

\begin{abstract}
Otan-Ile field, located in the transition zone Niger Delta, is characterized by complex structural deformation and faulting which lead to high uncertainties of reservoir properties. These high uncertainties greatly affect the exploration and development of the Otan-Ile field, and thus require proper characterization. Reservoir characterization requires integration of different data such as seismic and well log data, which are used to develop proper reservoir model. Therefore, the objective of this study is to characterize the reservoir sand bodies across the Otan-Ile field and to evaluate the petrophysical parameters using 3-dimension seismic and well log data from four wells. Reservoir sands were delineated using combination of resistivity and gamma ray logs. The estimation of reservoir properties, such as gross thickness, net thickness, volume of shale, porosity, water saturation and hydrocarbon saturation, were done using standard equations. Two horizons $(T$ and $U$ ) as well as major and minor faults were mapped across the 'Otan-Ile' field. The results show that the average net thickness, volume of shale, porosity, hydrocarbon saturation and permeability across the field are $28.19 \mathrm{~m}, 15 \%, 37 \%, 71 \%$ and $26,740.24 \mathrm{md}$ respectively. Two major faults $\left(F_{1}\right.$ and $\left.F_{5}\right)$ dipping in northeastern and northwestern direction were identified. The horizons were characterized by structural closures which can accommodate hydrocarbon were identified. Amplitude maps superimposed on depth-structure map also validate the hydrocarbon potential of the closures on it. This study shows that the integration of 3D seismic and well log data with seismic attribute is a good tool for proper hydrocarbon reservoir characterization.
\end{abstract}

Keywords Niger Delta $\cdot$ Well logs $\cdot$ Seismic $\cdot$ Reservoir characterization $\cdot$ Seismic attributes

\section{Introduction}

Tokunbo Sanmi Fagbemigun tsfagbemigun@gmail.com

1 Department of Geophysics, Federal University, Oye-Ekiti, Nigeria

2 Department of Applied Geophysics, Federal University of Technology, Akure, Nigeria

3 Department of Earth Sciences, Anchor University, Lagos, Nigeria

4 Department of Marine Science and Tech, Federal University of Technology, Akure, Nigeria

5 Boone Pickens School of Geology, Oklahoma State University, Stillwater, OK, USA

6 Department of Physics, Federal University, Oye-Ekiti, Nigeria

7 Department of Geology, Federal University, Oye-Ekiti, Nigeria
Niger Delta basin is ranked among the most prolific basins in the world and its productivity has made it to be the fulcrum of Nigeria economy. The 'Otan-Ile' field, located in the transition zone Niger Delta (Fig. 1). The basin is often characterized by complex structural deformation and faulting which could lead to high uncertainties in the reservoir properties (Doust and Omatsola 1990). These high uncertainties greatly affect the exploration and development of fields within the basin such as 'Otan-Ile' field. Improper interpretation of reservoir properties heterogeneity in the field has led to poor performance of reservoir during hydrocarbon production. Nonlinearity, natural heterogeneity and uncertainty of reservoir parameters make problems related to hydrocarbon characterization difficult (Koneshloo et al. 2018). Thus, it is problematic to clearly quantify spatial relationships of variable properties of reservoir. In resolving this problem, well logs and seismic data can be used to generate useful petrophysical parameters, maps and seismic attributes

Nigeria

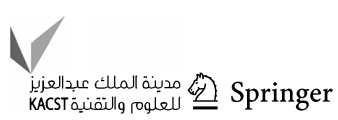



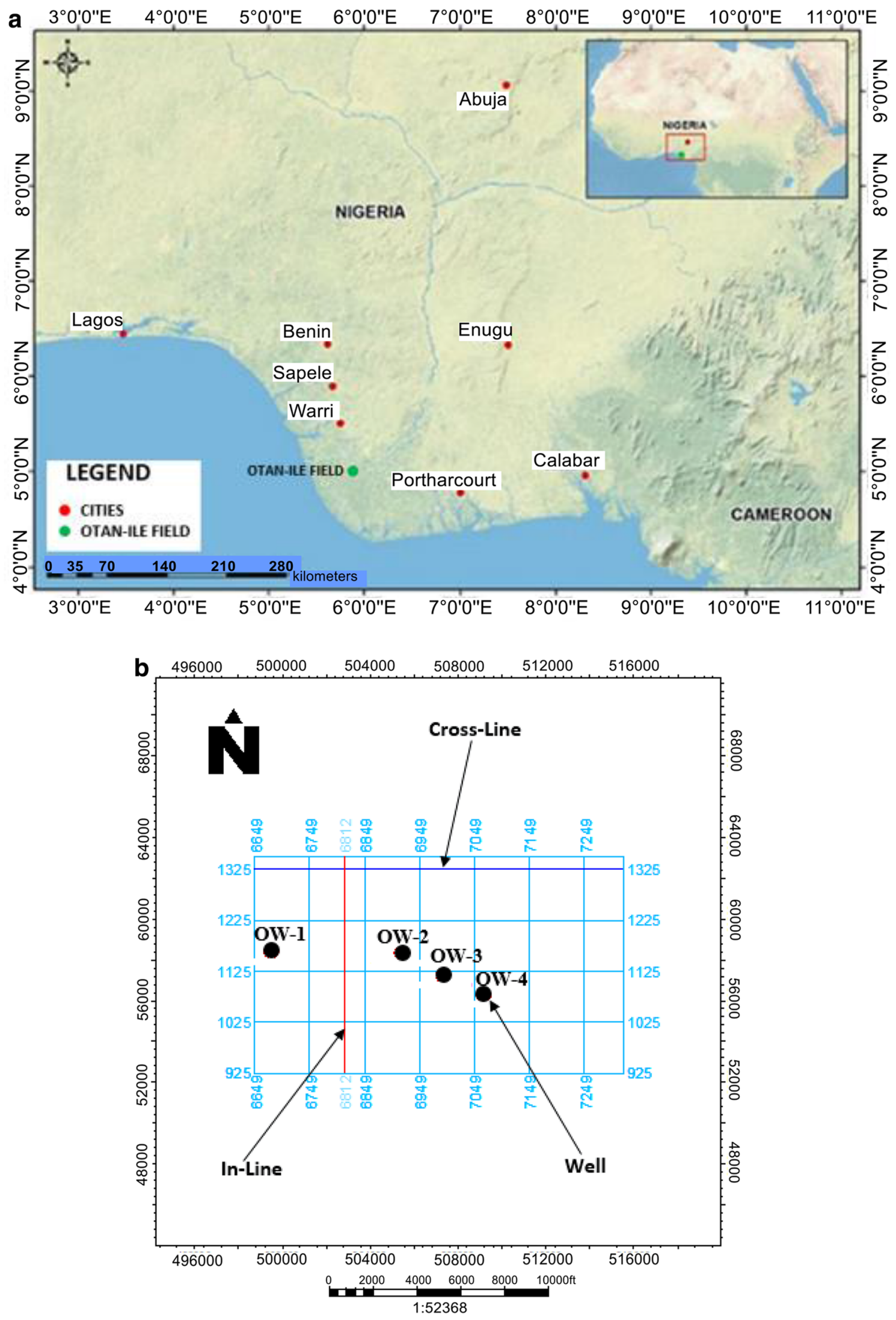

Fig. 1 a The Niger Delta Provinces (modified Edigbue et al. 2015). b Base Map of "Otan-Ile" Field 
which could provide detail description of reservoir properties and assist in optimal well placement. Concise geometric description of stratigraphic and structural aspects of a reservoir can be well achieved using well log and seismic data (Adelu et al. 2016; Sanuade et al. 2018; Akanji et al. 2018).

Several studies have been carried out in the Niger Delta Basin using 3D seismic and well log data to properly characterize hydrocarbon reservoirs (Sanuade et al. 2018; Ibe and Ezekiel 2019), for stratigraphical analysis (Emujakporue and Eyo 2019; Dim et al. 2019), volumetric analysis (Adelu et al. 2016; Akanji et al. 2016; Okpogo et al. 2018; Ukuedojor and Maju-Oyovwikowhe 2019), pore pressure prediction (Chiazor and Beka 2019; Tanko et al. 2019; Umoren et al. 2019) and structural analysis (Sanuade et al. 2018; Akanji et al. 2018; Adeoti et al. 2014; Ibe and Ezekiel 2018; Soneye and Osinowo 2019). Furthermore, seismic attributes (measure of seismic data which aids to improve visualize or quantify structures of interpretation concern (Marfurt and Chopra 2007) are very important tools in analyzing and interpreting hydrocarbon reservoir as they provide detailed information. Seismic attribute maps have also been used by several researchers to enhance hydrocarbon characterization (Adelu et al. 2016; Sanuade et al. 2018; Akanji et al. 2018; Ibe and Ezekiel 2019).

Therefore, the objective of this study is to characterize the complex reservoir bodies in the Otan-Ile field and to evaluate the petrophysical parameters so as to provide detailed geological information about the field.

\section{Geology of the study area}

\section{Structure and Sedimentology of Niger Delta}

The structure of the Niger Delta basin is comparable to a colossal rollover, with paralic shales and sands acting as the principal sediments present. The latter sequence prevails at 1930-2050 m within the subsea (Short and Stauble 1967; Whiteman 1982; Doust and Omatsola 1990).

The three key formations within the Niger Delta basin are the bottom Akata, middle Agbada and topmost Benin Formations (Fig. 2). The first, newest, coastal plain, Miocene to Recent Benin Formation (Short and Stauble 1967; Evamy et al. 1978; Ejedawe 1986; Doust and Omatsola 1990) largely consists of deposits of alluvia and non-marine sandstones, in a continental, yet fluvial setting, encompassing the western flank of the Niger Delta complex to the total basin and the southern region of the shoreline. Bands of gravel lignite, wood fragments, minute intercalations of shales and coarse-grained sandstones are prime deposits observed. It is also primarily linked with infinitesimal accumulation of hydrocarbon (Akanji et al. 2018). The thickness of this Formation varies widely, exceeding $1820 \mathrm{~m}$ in some instances.

The underlying lower Agbada Formation, is a chief petroleum-bearing, Eocene to Pliocene Formation, which is situated within varying environments from a coastal brackish and/or marine one to a fluvial one. There are equivalent layers and quantities of sandstone and shale at the basal region

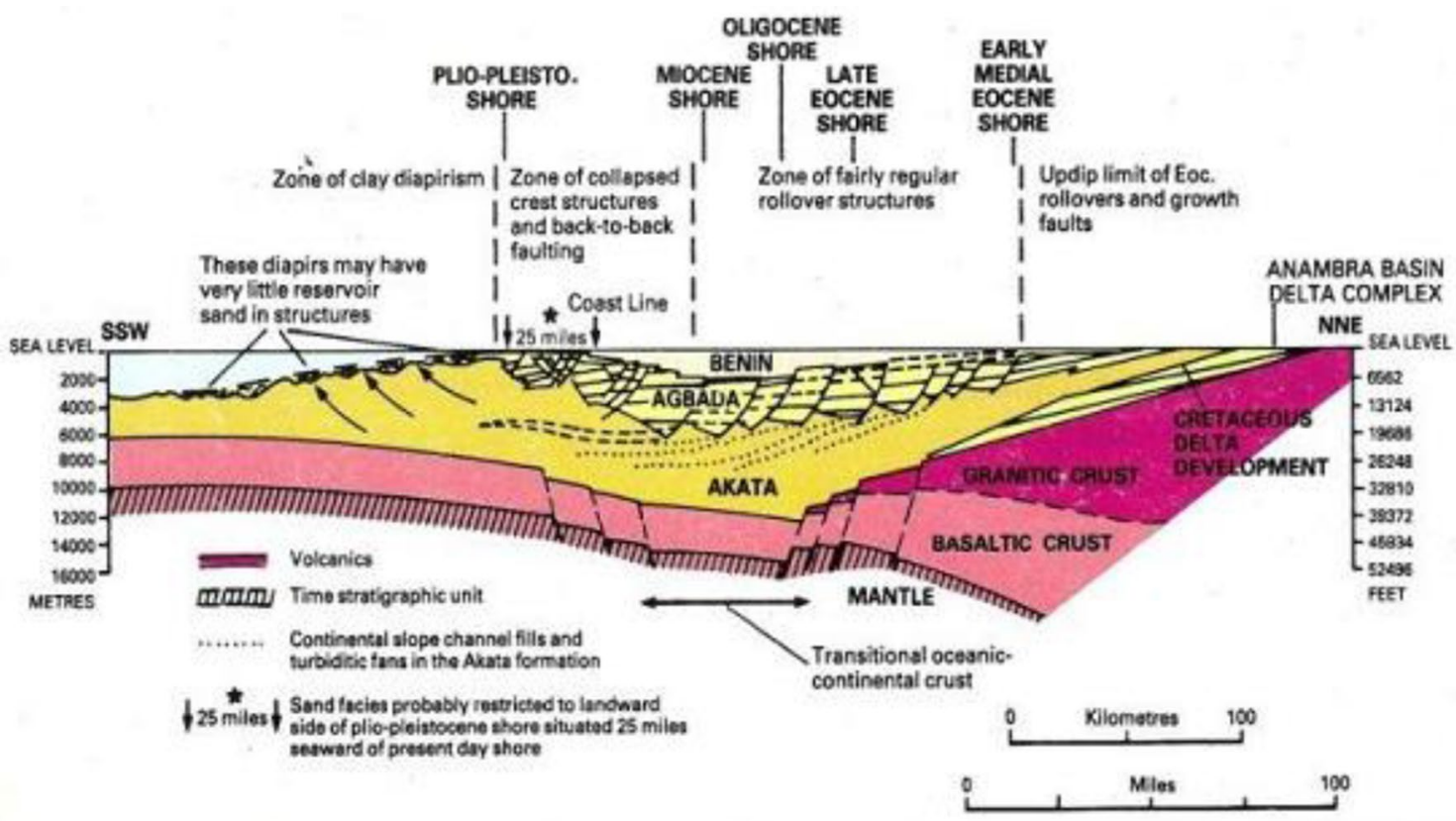

Fig. 2 Structural units of the Niger Delta complex (Short and Stauble 1967)

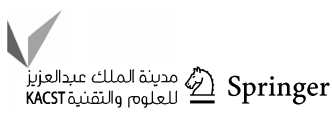




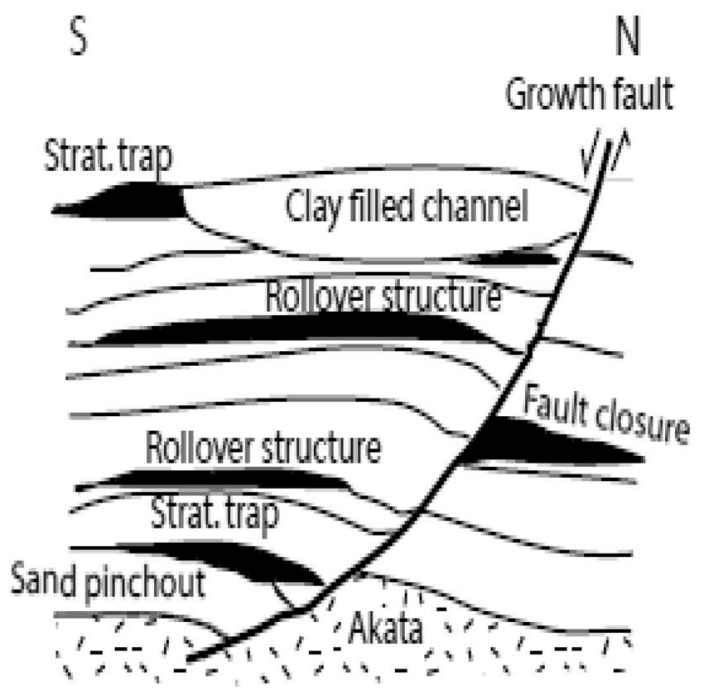

Simple rollover structure with clay filled channel

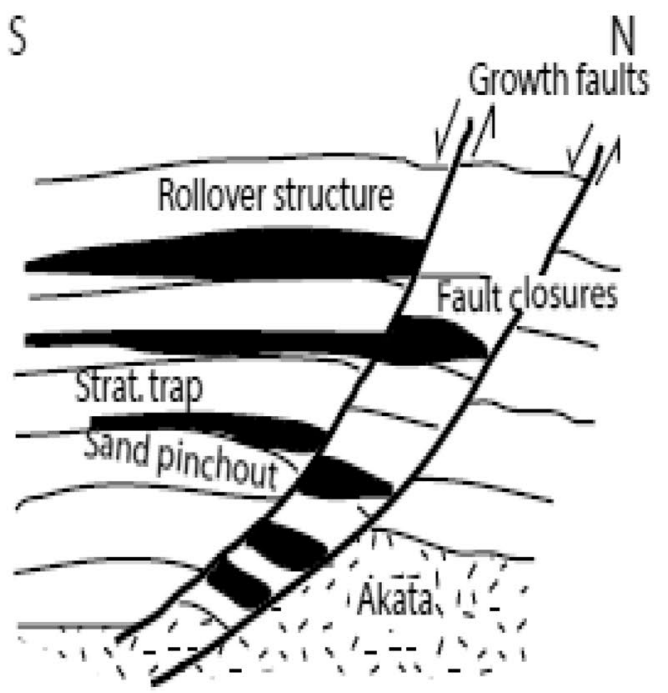

Structure with multiple growth faults

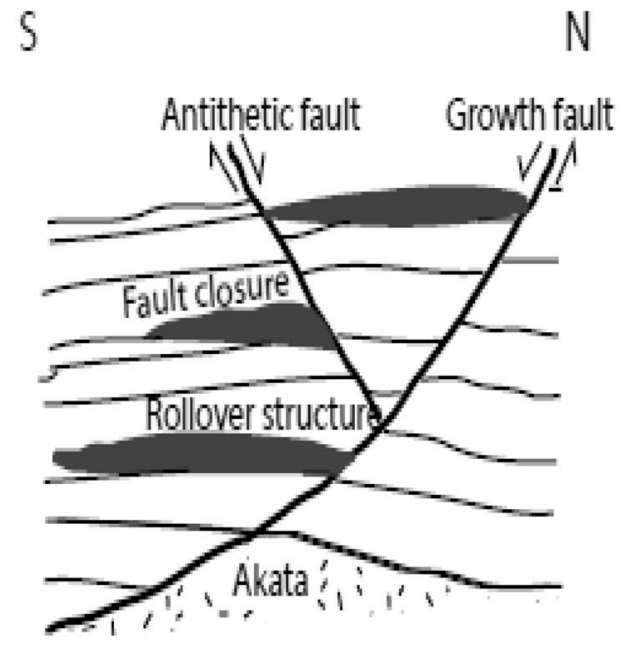

Structure with antithetic fault

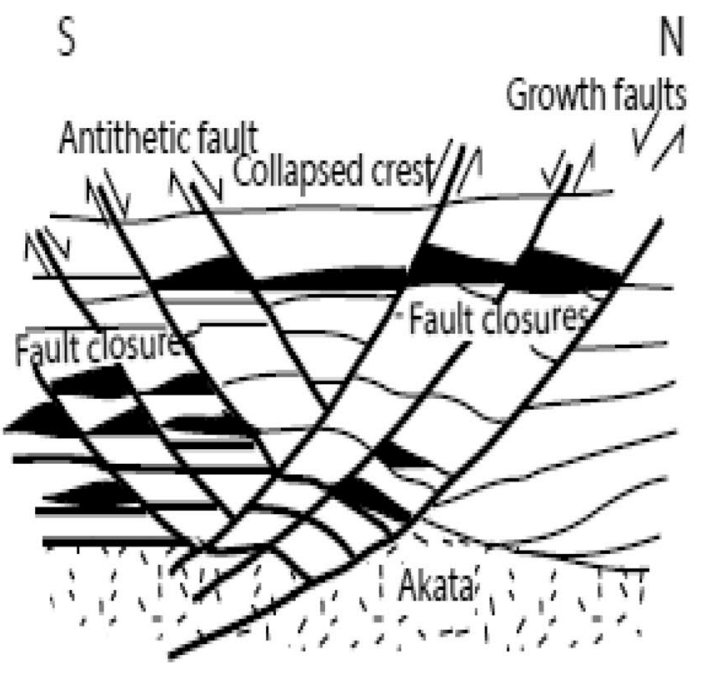

Collapsed crest structure

Fig. 3 Example of Niger Delta oil field structures and associated traps types (Doust and Omatsola 1990)

with more sands in the upper layer. Furthermore, in the basal layer, shales result from gradual variation of unconsolidated to marginally consolidated sandstones which are well graded with varying degrees of roundness. The sands host the hydrocarbon, acting as reservoirs with the shales offering effective closures and seals (Bustin 1988; Corredor et al. 2005; and Adeoti et al. 2014). Here, there are several orientations of the belts hosting massive quantities of oil, and a maximum thickness of $4500 \mathrm{~m}$ is observed (Evamy et al. 1978; Doust and Omatsola 1990; Dieokuma et al. 2014).
The ancient, bottom, marine Akata Formation is about $7000 \mathrm{~m}$ thick, with an age range from Eocene to Recent exhibits signs of excess overburden pressure; and resembles a diapir from the offshore continental slope. It is made up of dense series of the potential hydrocarbon source rock (shale), turbidites and insignificant amounts of clays and silts (Doust and Omatsola 1990). The shales also host local siltstones and sandstones as interbeddings (Haack et al. 2000). 
Northwest to southeast and northeast to southwest trending growth faults-antithetic, flank, regional, crestal, structure-building and listric faults; ridges, rollover anticlines and shale diapirs are associated with the Niger Delta basin (Hosper 1971). The Niger Delta comprises depobelts/megaunits which are objects with respect to distribution of hydrocarbon, stratigraphy and structure-building (Evamy et al. 1978). The improvement and style of the discrete megaunits are connected to the equilibrium between the rate of sediment subsidence and supply (Knox and Omatsola 1989). Doust and Omatsola (1990) described a variety of structural trapping elements, including those associated with simple rollover structures; clay filled channels, structures with multiple growth faults, structures with antithetic faults and collapsed crest structures (Fig. 3).

\section{Methodology}

\section{Database}

The data used for this study include 3D seismic data (covering an area of $51 \mathrm{~km}^{2}$ ), well log from four wells (sonic, density, gamma ray and resistivity) and checkshot data.

\section{Methodology}

\section{Lithology delineation}

The methodology used in this study include identifying lithology by using gamma ray log. The lithology was identified by defining the shale base line to be 65 API (American Petroleum Institute) (Asquith and Krygowski 2004) which is a constant line in front of shale Formation across the entire 'Otan-Ile' field. A deflection, even slight from the shale base line to the left, indicates a sand Formation. Delineation of petroliferous zones was done by using combination of gamma ray and resistivity logs. When sand Formation correlates with relatively high resistivity response, such is recognized as petroliferous zone.

\section{Petrophysical evaluation}

Standard equations were used for the estimation of reservoir properties, which involves calculation of reservoir parameters such as gross thickness, net thickness, volume of shale, porosity, water saturation and hydrocarbon saturation of the field.

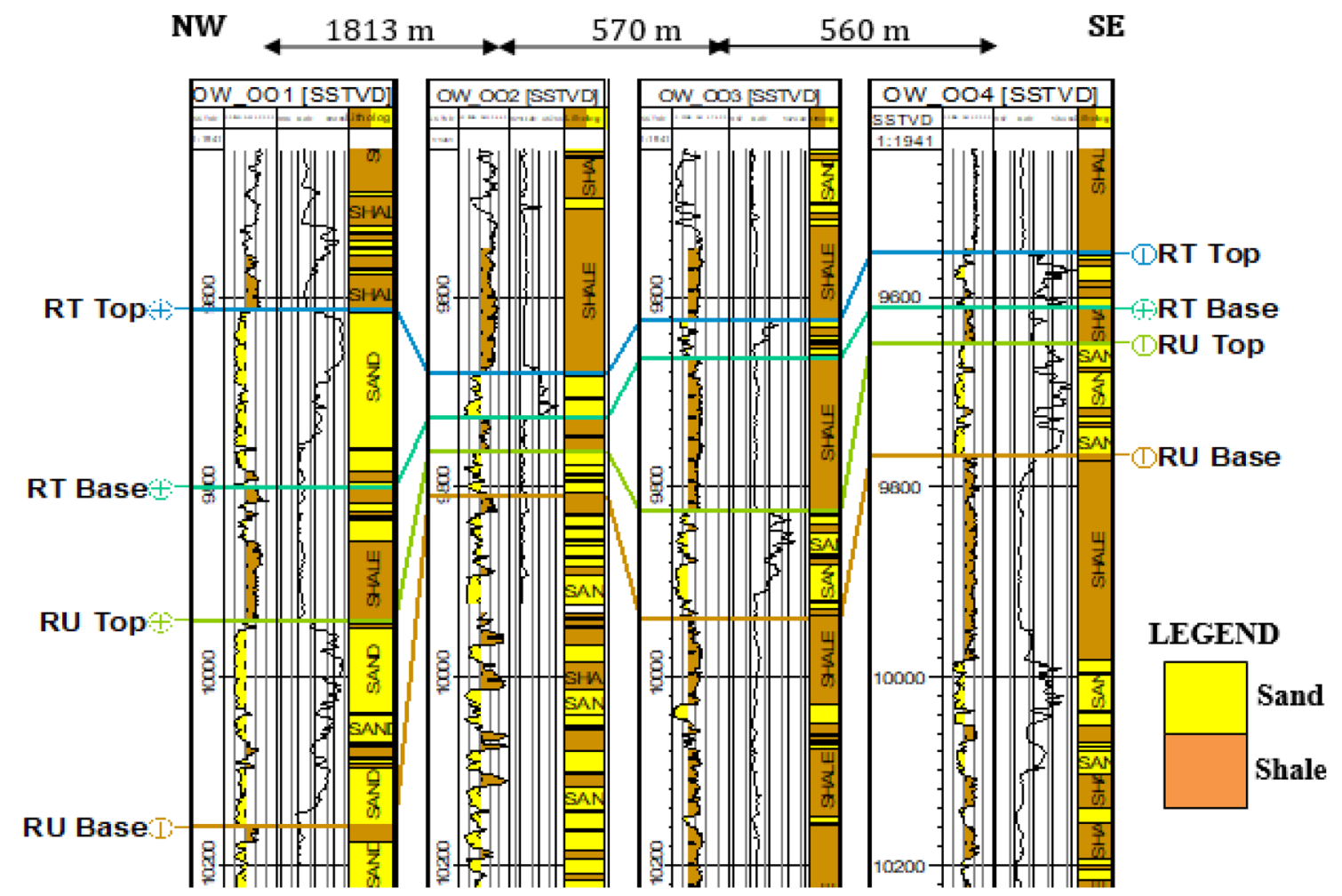

Fig. 4 Lithostratigraphic well correlation of reservoirs $T$ and $U$ along West-East direction 
Table 1 Computed petrophysical parameters of the studied wells

\begin{tabular}{|c|c|c|c|c|c|c|c|}
\hline Wells & Reservoirs & $\begin{array}{l}\text { Gross thick- } \\
\text { ness (m) }\end{array}$ & Net thickness (m) & $V_{\text {shale }}(\%)$ & $\begin{array}{l}\text { Effective poros- } \\
\text { ity }(\%)\end{array}$ & $\begin{array}{l}\text { Hydrocarbon } \\
\text { saturation (\%) }\end{array}$ & Permeability (md) \\
\hline \multirow[t]{2}{*}{ OW-1 } & Sand $\mathrm{T}$ & 57.38 & 48.20 & 16 & 37 & 68 & $61,004.57$ \\
\hline & Sand U & 67.39 & 55.26 & 18 & 32 & 60 & $18,684.89$ \\
\hline \multirow[t]{2}{*}{ OW-2 } & Sand T & 14.37 & 7.61 & 59 & 20 & 80 & 405.43 \\
\hline & Sand U & 14.18 & 12.05 & 15 & 29 & 65 & 8376.49 \\
\hline \multirow[t]{2}{*}{ OW-3 } & Sand $\mathrm{T}$ & 12.27 & 11.53 & 6 & 30 & 80 & $11,042.22$ \\
\hline & Sand U & 34.62 & 30.82 & 11 & 31 & 66 & $14,425.01$ \\
\hline \multirow[t]{2}{*}{ OW-4 } & Sand T & 17.89 & 16.64 & 7 & 39 & 80 & $93,690.35$ \\
\hline & Sand U & 36.08 & 32.11 & 11 & 28 & 65 & 6292.98 \\
\hline
\end{tabular}

Table 2 Porosity and Permeability values for Reservoirs Qualitative Description (Rider 1986)

\begin{tabular}{lllll}
\hline \multicolumn{2}{l}{ Qualitative evaluation of porosity } & \multicolumn{2}{l}{$\begin{array}{l}\text { Qualitative evaluation of perme- } \\
\text { ability }\end{array}$} \\
\cline { 1 - 1 } Porosity (\%) & $\begin{array}{l}\text { Qualitative descrip- } \\
\text { tion }\end{array}$ & $\begin{array}{l}\text { Average km } \\
\text { value (md) }\end{array}$ & $\begin{array}{l}\text { Qualitative } \\
\text { description }\end{array}$ \\
\hline 0.5 & Negligible & $<10.5$ & Poor to fair \\
$5-10$ & Poor & $15-50$ & Moderate \\
$15-20$ & Good & $50-250$ & Good \\
$20-30$ & Very good & $250-1000$ & Very good \\
$>30$ & Excellent & $>1000$ & Excellent \\
\hline
\end{tabular}

\section{Volume of Shale}

The data obtained from gamma ray log was used to achieve this. The volume of shale $\left(V_{\text {sh }}\right)$ was mathematically computed using Eq. 1 (Asquith and Krygowski 2004): $v_{\mathrm{sh}}=0.083\left(2^{3.7 I_{\mathrm{GR}}}-1\right)$

where $\mathrm{I}_{\mathrm{GR}}$ can be estimated using Eq. 2 .

$I_{\mathrm{GR}}=\frac{\mathrm{GR}_{\mathrm{log}}-\mathrm{GR}_{\min }}{\mathrm{GR}_{\max }-\mathrm{GR}_{\min }}$

where $\mathrm{GR}_{\max }$ is gamma ray maximum (shaly sand); $\mathrm{GR}_{\min }$ is gamma ray minimum from clean sand; $\mathrm{GR}_{\log }$ is gamma ray $\log$ (shaly-sand); $I_{\mathrm{GR}}$ is the gamma ray index.

Porosity

The porosity is a measure of the amount of internal space that is capable of holding fluid. It is expressed in percentage (\%) (Asquith and Krygowski 2004). Porosity was estimated from the sonic log using Eq. 3:

$\emptyset_{\text {sonic }}=\left(\frac{\Delta t_{\log }-\Delta t_{\mathrm{ma}}}{\Delta t_{\mathrm{f}}-\Delta t_{\mathrm{ma}}}\right)$

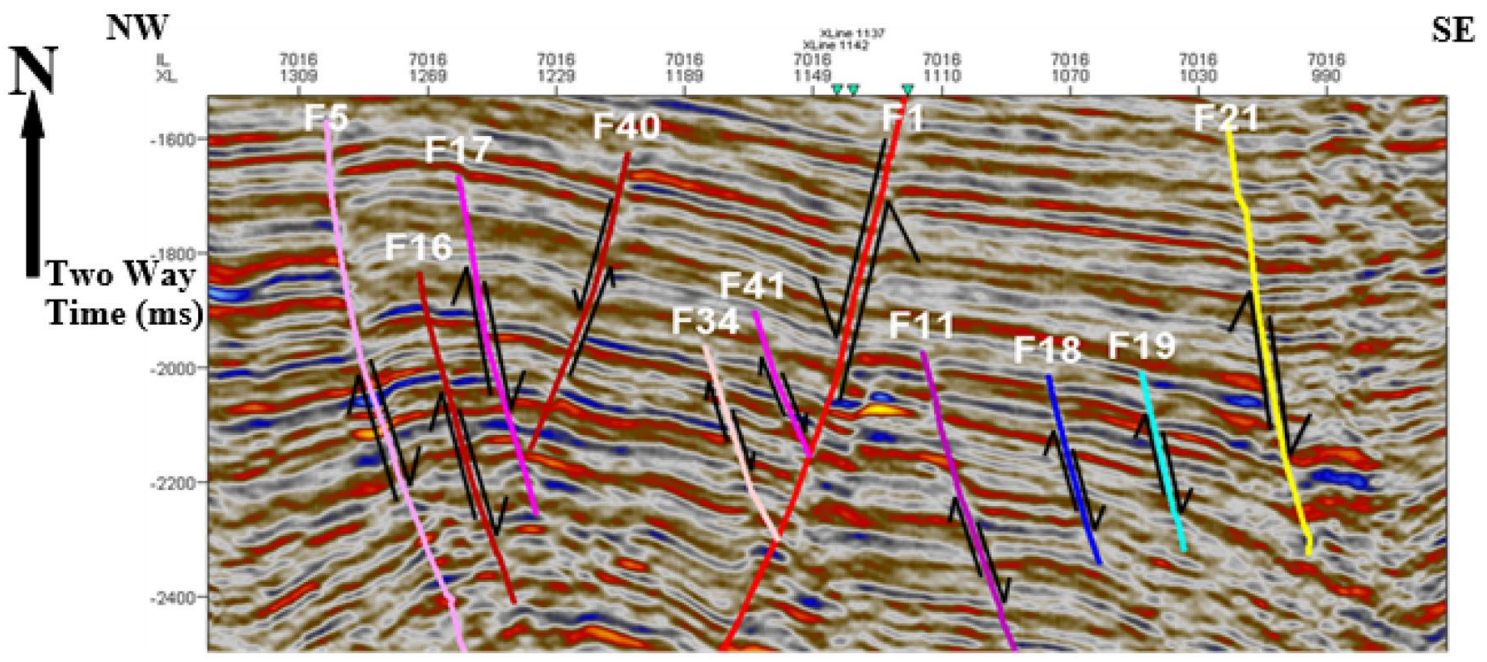

Fig. 5 Some of the faults mapped showing on inline 7016 


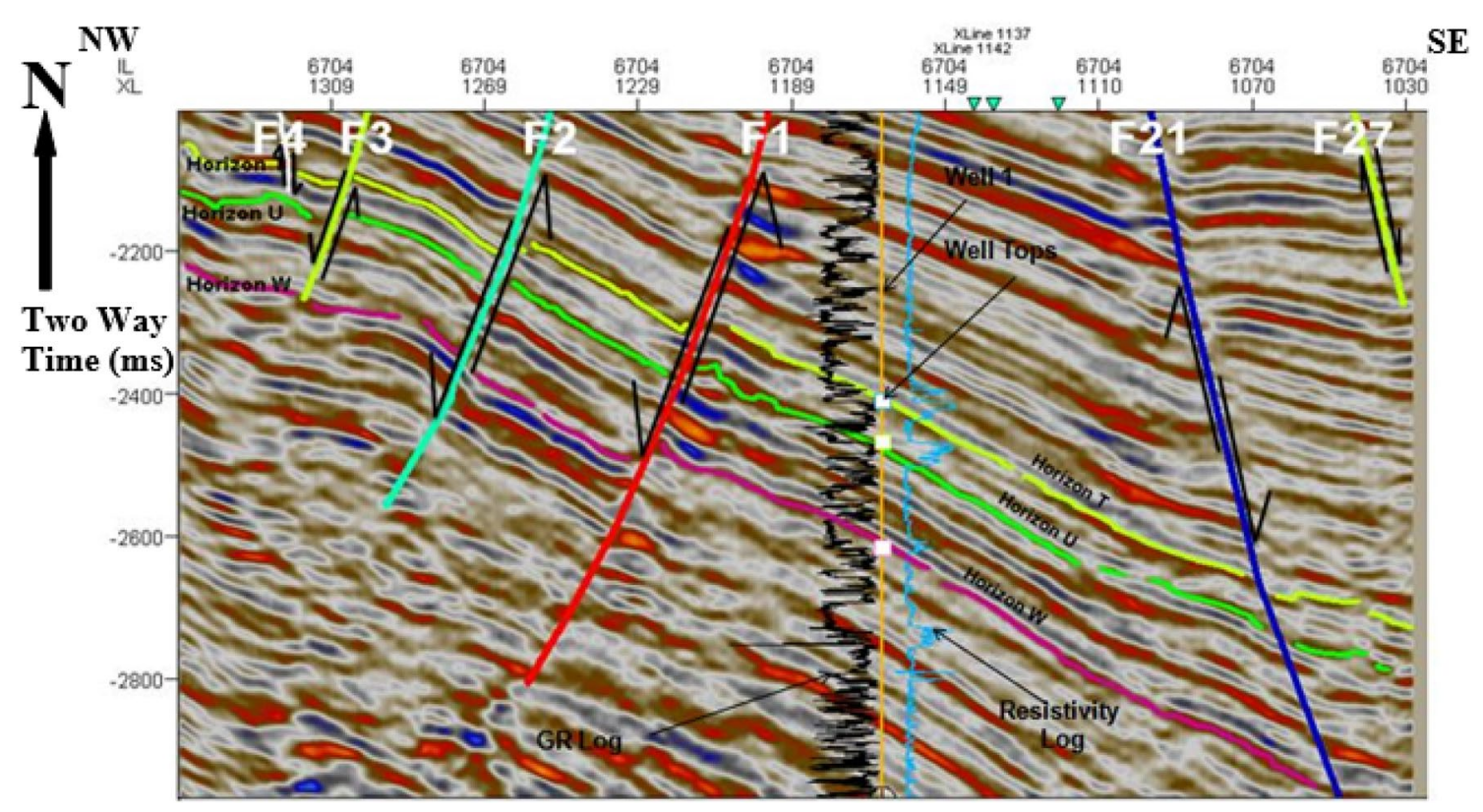

Fig. 6 Inline 6704 displaying horizons mapped, well tops and well log

Table 3 Computed throws of the two major faults $F_{1}$ and $F_{5}$

\begin{tabular}{llllll}
\hline Horizon & \multicolumn{2}{l}{ Fault throw $\left(F_{1}\right)$} & & \multicolumn{2}{l}{ Fault throw $\left(F_{5}\right)$} \\
\cline { 2 - 3 } \cline { 6 - 7 } & $\mathrm{ft}$ & $\mathrm{m}$ & & $\mathrm{ft}$ & $\mathrm{m}$ \\
\hline $\mathrm{T}$ & 159.57 & 48.64 & & 93.73 & 28.57 \\
$\mathrm{U}$ & 155.38 & 47.36 & & 157.06 & 47.87 \\
\hline
\end{tabular}

where $\varphi_{\text {sonic }}=$ Sonic-derived porosity; $\Delta t_{\mathrm{ma}}=$ Interval transit time of matrix; $\Delta t_{\log }=$ Interval transit time of formation; $\Delta t_{\mathrm{f}}=$ Interval transit time of the fluid in the well bore (fresh $\operatorname{mud}=620 \mu \mathrm{s} / \mathrm{m}$ salt $\mathrm{mud}=607 \mu \mathrm{s} / \mathrm{m}$. The sonic log only records matrix porosity rather than fracture or secondary porosity.

Water Saturation $\left(S_{\mathrm{w}}\right)$

Water saturated was estimated using Eqs. 4-6 (Archie 1942).

$$
\begin{aligned}
& F=\frac{R_{\mathrm{o}}}{R_{\mathrm{w}}} \\
& S_{\mathrm{w}}^{\mathrm{n}}=\frac{F \cdot R_{\mathrm{w}}}{R_{\mathrm{t}}}
\end{aligned}
$$

$S_{\mathrm{w}^{2}}=\frac{R_{\mathrm{o}}}{R_{\mathrm{t}}}$

where $S_{\mathrm{w}}=$ water saturation; $F=$ formation Factor; $R_{\mathrm{w}}=$ Formation water resistivity at formation temperature; $R_{\mathrm{o}}=$ Resistivity of formation at $100 \%$ water saturation; $R_{\mathrm{t}}=$ True formation resistivity; $n$ Saturation exponent. This is usually two.

\section{Hydrocarbon saturation}

Hydrocarbon saturation $\left(\mathrm{S}_{\mathrm{h}}\right)$ was calculated using Eq. 7

$S_{\mathrm{h}}=1-S_{\mathrm{w}}$

\section{Permeability}

Permeability was estimated using Eqs. 8 (Asquith and Krygowski 2004):

$K=\left[\frac{250 x \emptyset^{3}}{S_{\mathrm{w} \text { irr }}}\right]^{2}$

where $\mathrm{K}=$ Permeability; $\Phi=$ Porosity; $\mathrm{S}_{\mathrm{w} \text { irr }}=$ Irreducible water saturation.

\section{D seismic interpretation}

Fault identification on the seismic section was centered on reflection discontinuity, vertical displacement of reflection, mis-closures in tying reflections around loops, sudden cessation of events and change in shape of events transversely the faults. The tops of petroliferous zones were tied to the

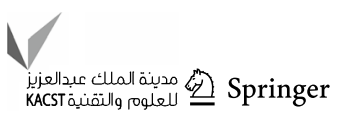




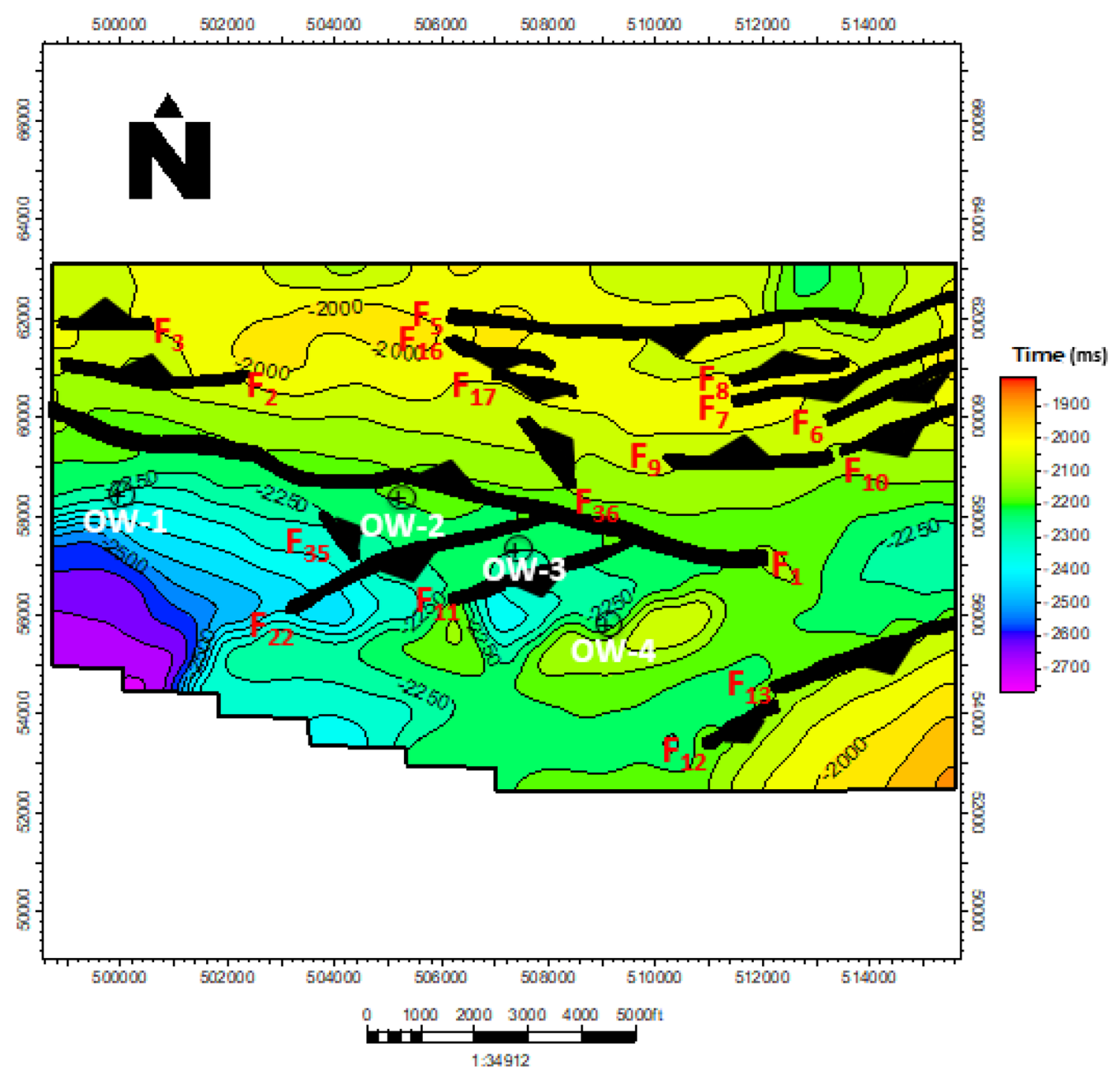

Fig. 7 Map of time-structure of horizon $T$

seismic section to identify two horizons ( $\mathrm{T}$ and $\mathrm{U}$ ) through seismic-to-well tie based on the continuity, event strength, amplitude and coherency and prospectivity. Two horizons were mapped across the 3D seismic volumes; and time, depth and attribute contour maps were generated for the horizons. Seismic attributes gives an idea of the verticallateral variations of the reservoirs in the subsurface. Having completed the horizon and fault mapping; an attempt to complement the conventional interpretation was undertaken using attribute analysis. The two attributes utilized were root mean square and maximum amplitudes.

\section{Results and discussion}

\section{Well log data interpretation}

Two reservoirs sand bodies (Sand $T$ and $U$ ) were delineated across the 'Otan-Ile' field from four wells: OW-1, OW-2, OW-3 and OW-4 (Fig. 4). The general stratigraphy comprised intercalation of sand and shale layers. The shale strata increase in thickness with respect to depth, while the sand layers decrease in thickness with depth. This is typical of rock sequence within the Agbada Formation (Anthony and Aurelius 2013; Akanji et al. 2018). The sand bodies thinning southeastern direction of 'Otan-Ile' field implying the direction of deposition or erosion as highlighted by (Catuneanu 2006). The reservoir sand bodies' gross thickness, 


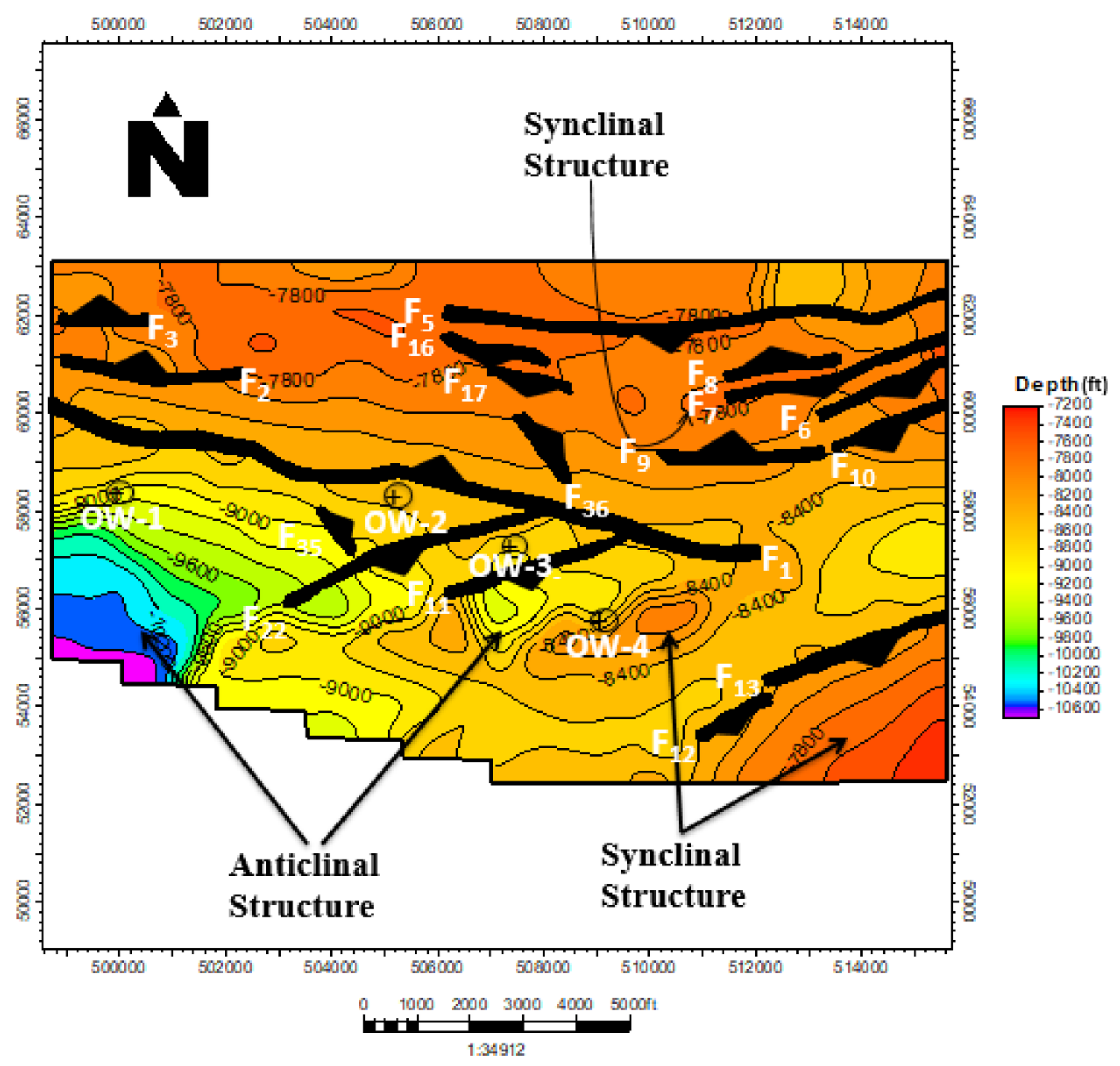

Fig. 8 Map of depth-structure of horizon $T$

net thickness, volume of shale, effective porosity, hydrocarbon saturation and permeability vary from $12.27-67.39 \mathrm{~m}$, 7.61-55.26 m, 6-59\%, 20-39\%, 60-80\% and 405.43-93, $690.35 \mathrm{md}$, respectively, across the field (Table 1). The average gross thickness of reservoir sand bodies across the wells is $31.76 \mathrm{~m}$. The average effective porosity ( $31 \%)$ and permeability $(26,740.24 \mathrm{md})$ of the field show it is viable in terms of porosity and permeability (Buller et al. 1970; Ibe and Ezekiel 2019). This plays a vital role in releasing of hydrocarbon from the reservoir. The petrophysical parameters of this field have similarity with some of the works that had been carried out in Niger Delta (Adeoti et al. 2014; Adelu et al. 2016; Sanuade et al. 2018; Akanji et al. 2018). The porosity and permeability values of the field satisfied the porosity and permeability values for reservoirs qualitative description by Rider (1986) (Table 2). The field varies from very good to excellent in terms of porosity and permeability. 


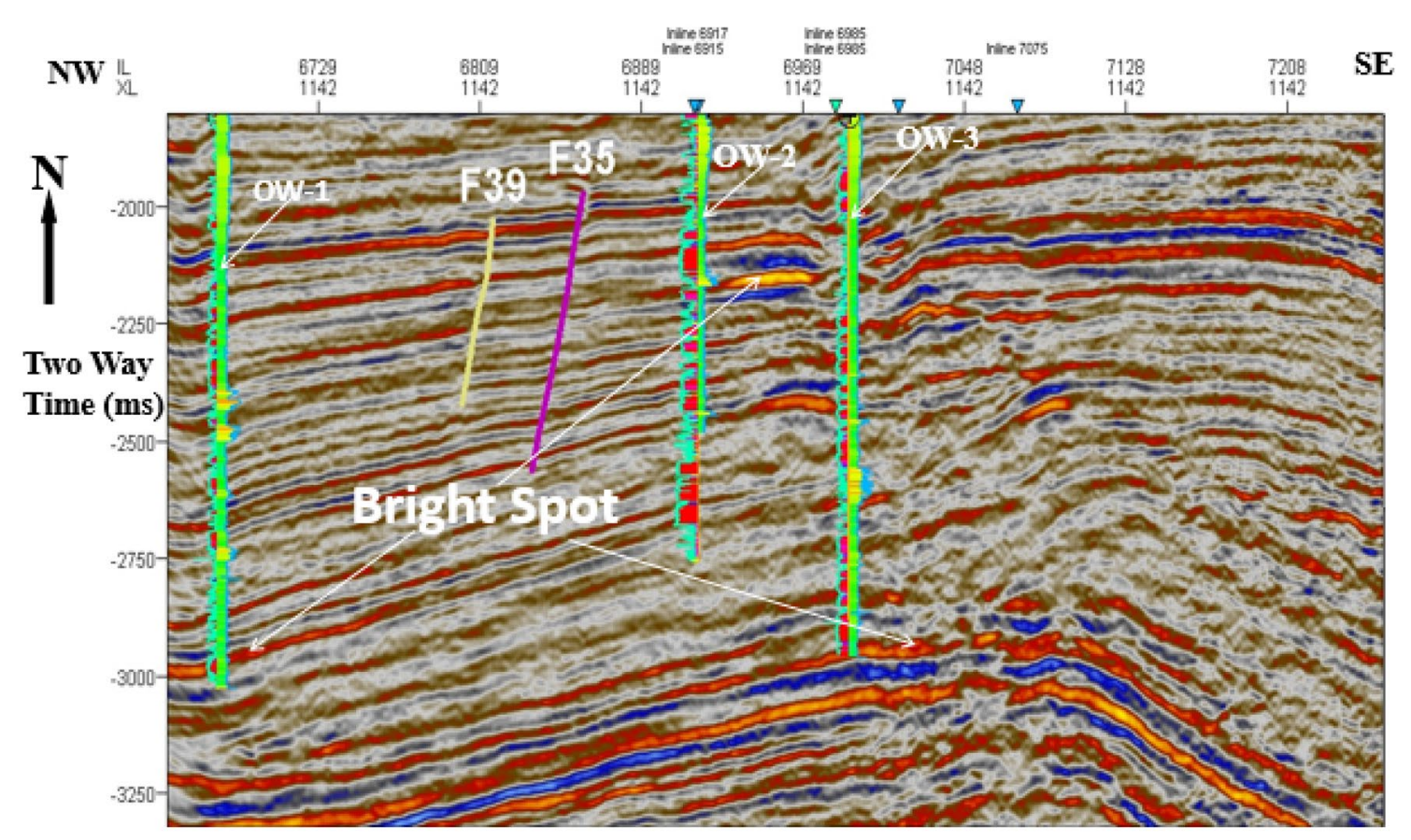

Fig. 9 Relative acoustic impedance attribute displaying the high amplitude (bright spots) as indicator of hydrocarbon

\section{Seismic data interpretation}

Faults $F_{1}, F_{2}, F_{5}, F_{17}$ and $F_{21}$ are the major growth faults delineated in the 'Otan-Ile' field, while the minor faults are $F_{3}, F_{4}, F_{11}, F_{16}, F_{18}, F_{19}$ and $F_{34}$ (Fig. 5). Both antithetic ( $F_{34}$ and $\left.F_{41}\right)$ and synthetic $\left(F_{1}\right)$ faults were identified in the field (Fig. 5). The throw of the major faults increases with depth, which may serve as migration path and the minor faults are characterized with small throws, which could be acting as a seal in the field. The faults could serve as trap and most of them form potential sites for thick sediment accumulation in the down thrown region as described by Short and Stauble (1967). Figure 6 has well OW-4 projected on to it, which validates that proper horizon was mapped and the extensiveness of the petroliferous layers.

Primary seal rocks in the Niger Delta are the inter-bedded shale within the Agbada Formation, the juxtaposition of reservoir sands against shale beds due to faulting creates good seal integrity (Doust and Omatsola 1990). The shale provides seals in the form of clay smears along these syn-sedimentary faults and vertical fault seals in a compressive stress setting (Weber and Daukoru 1975).

The sealing capability of the faults is dependent on the amount of throws and shale/clay smeared along the fault planes (Busch 1975; Weber and Daukoru 1975). According to Weber and Daukoru (1975), faults can be sealing if either the throws are less than $492 \mathrm{ft}(150 \mathrm{~m})$, or the amount shale/ clay smeared along the fault planes is greater than $25 \%$. The average throws of the major faults $F_{1}$ and $F_{5}$ calculated are $134.88 \mathrm{ft}(41.11 \mathrm{~m})$ and $125.4 \mathrm{ft}(38.22 \mathrm{~m})$, respectively (Tables 3). Therefore, based on the amount of throws, faults $F_{1}$ and $F_{5}$ are sealing which is in agreement with the work by Weber and Daukoru (1975), signifying that in the Niger Delta, the soft and over- pressured Akata Shale, in most cases rise up to fill the fault zones, thus enhancing their sealing capabilities.

The time horizon map of Horizon $\mathrm{T}$ in Fig. 7 shows that the anticlinal structure observed on this surface is heavily faulted. Major faults associated with this structure are faults $F_{1}$ and $F_{5}$. Faults $F_{22}$ and $F_{11}$ are antithetic to fault $F_{1}$. Minor faults include faults $F_{2}, F_{3}, F_{6}, F_{7}$ and $F_{8}$. The 


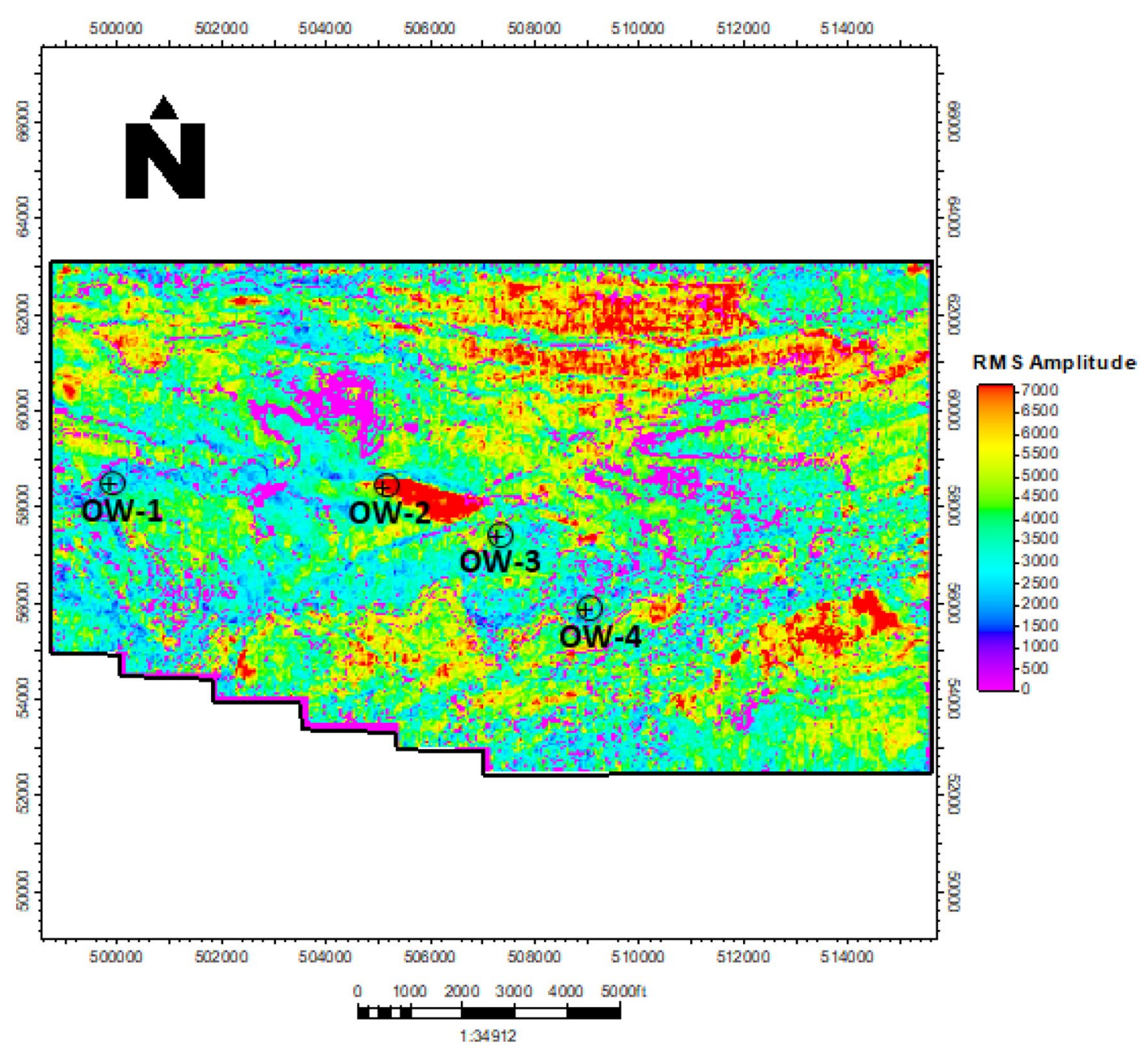

Fig. 10 Map of RMS amplitude attribute of horizon $T$

probable structures accumulating oil and gas in this field are fault-assisted closures. On the depth structural map (Fig. 8), the two major closures identified at southeastern region are structurally controlled, which are four-way closures. These two major structural closures possess efficient traps suitable for hydrocarbon accumulation. The potential of trapping in the "Otan-Ile" field can be attributed to faults and/or anticlines, acting either as fault aided or anticline closures correspondingly or both.

The relative acoustic impedance attribute, which is volume seismic attribute, shows areal range of the bright spots (sweet spots) of several seismic attributes determined for reservoir sand bodies (Fig. 9). The detected sturdy reflection is a suggestive of reservoir rocks, which may be owing to the manifestation of hydrocarbons in the delineated layers (sands). It is observed here that, the existing wells target the observed bright spots for production, which supports the effectiveness of seismic attributes in optimal well placement.

Figures 10 and 11 show the root mean square (RMS) and maximum amplitude maps. The high amplitude form observed around the exiting well positions on the attribute maps indicate bright spot, which may be produced by a locally greater-than-normal velocity dissimilarity amid two strata or a decrease in the acoustic impedance from the overlaying shale to the sand reservoir saturated with hydrocarbon. The high amplitude areas are in patches on the attribute 


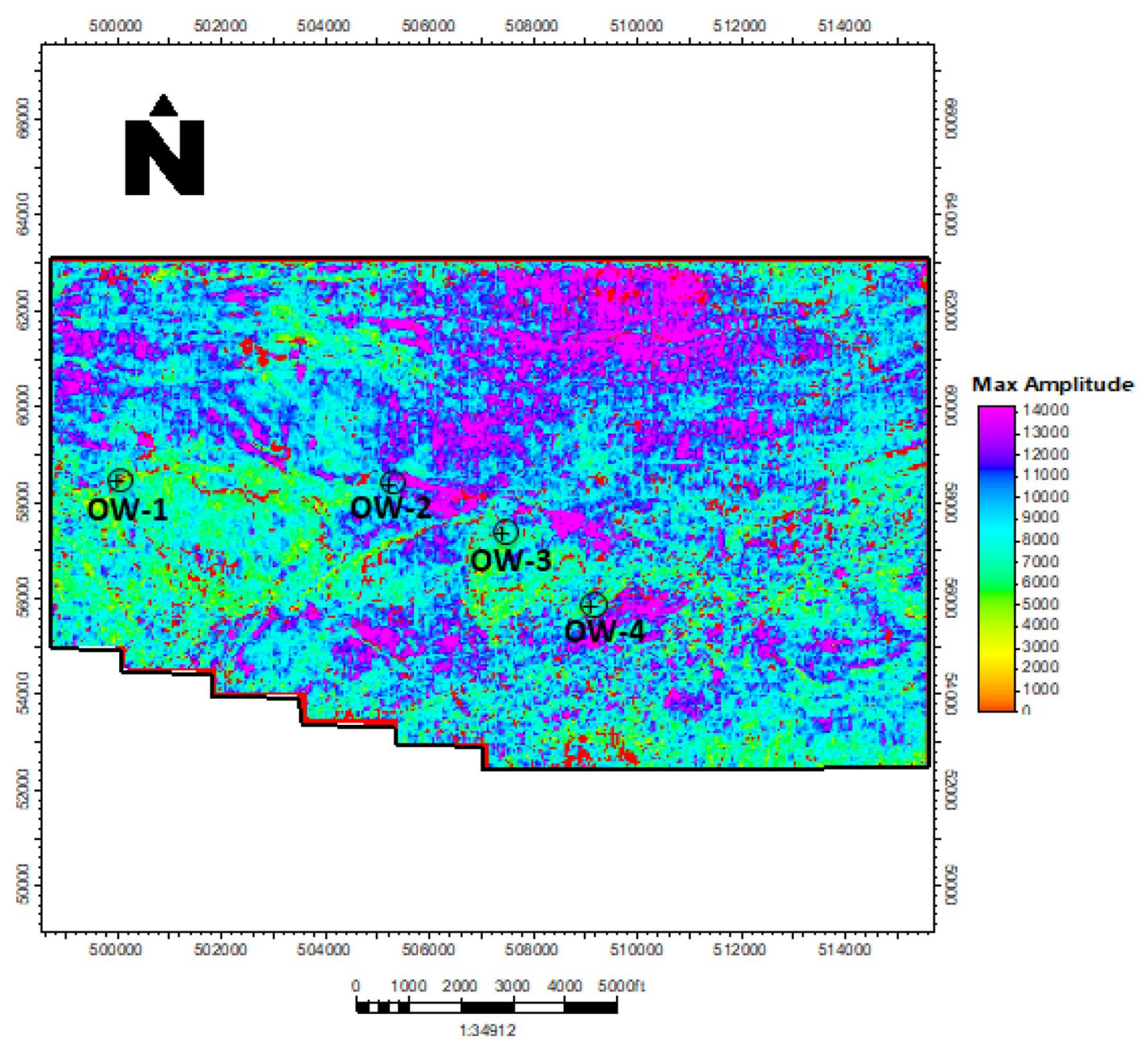

Fig. 11 Map of maximum amplitude attribute of horizon $T$

maps and it is more distinct at the northern part of the maps. It was observed that OW-2 lies directly on high amplitude. The behavioral pattern of amplitude distribution on maximum attribute conforms to the RMS map as distinct zones of anomalous amplitude in northern and central parts of the map were observed.

Figures 12 and 13 show the depth-structure maps superimposed on RMS attribute maps of the horizons. The bright spot (high amplitude) observed on the upthrown of one of the main structural building, major growth fault $\left(\mathrm{F}_{1}\right)$ and on the downthrown of the synthetic fault $\left(\mathrm{F}_{9}\right)$ supports the outcome from the maps of depth overlaid on the map of amplitude. The closures observed on depth-structure maps conform to high amplitude.

\section{Conclusion}

The reservoir properties of the 'Otan-Ile' field in the transition zone, Niger Delta, have been characterized using 3D seismic and well log data. Two reservoir sand bodies were delineated crosswise the available wells. The estimated 


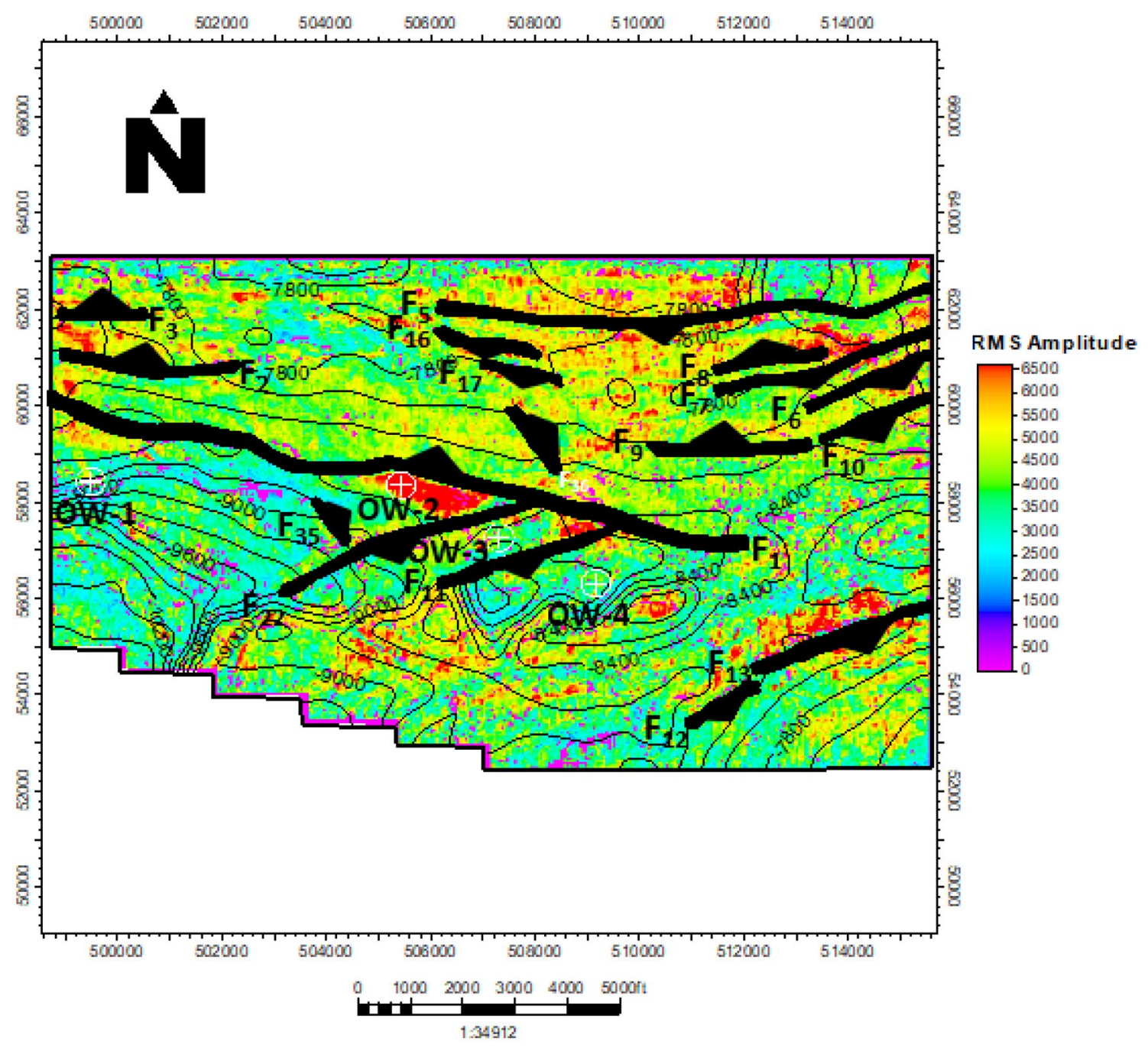

Fig. 12 Depth-structure map superimposed on RMS amplitude of horizon $T$

petrophysical properties show that the field is viable in terms of hydrocarbon production. The growth fault, $\mathrm{F}_{1}$ nearly cut across the field and increases in throw with depth and could serve as trap for hydrocarbon in the field. The time and structural maps revealed the geometry of the subsurface and nature of hydrocarbon reservoir in the field, which are fault-assisted structural and anticlinal closures. The attribute maps generated conformed to the structural highs observed on time and depth maps, which hereby validate the integrity of their interpretation. It has been shown from this study that the integration of 3D seismic and well log data can be used for hydrocarbon reservoir characterization and the information from this study would aid proper management of the reservoirs in the Otan-Ile field. 


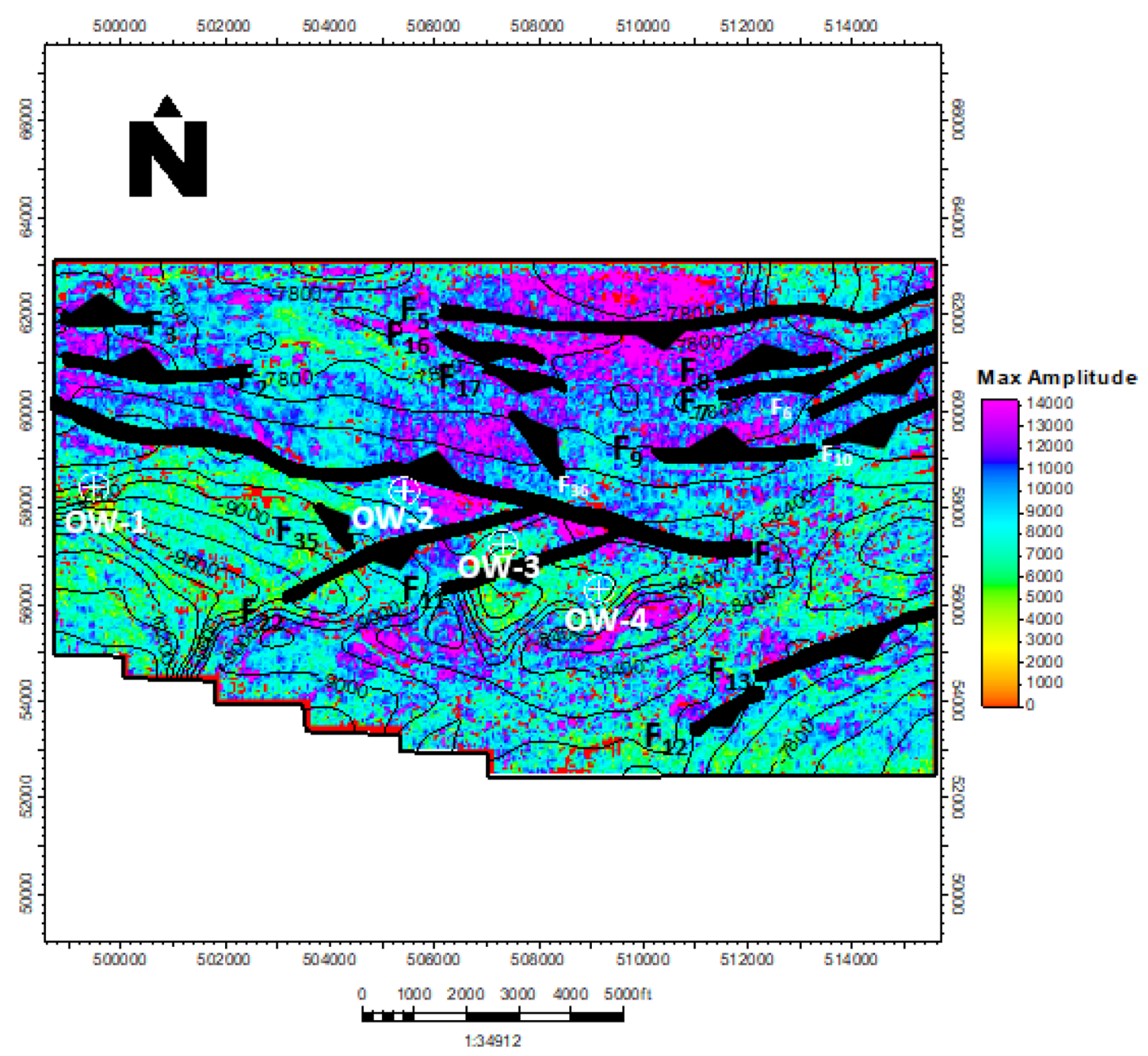

Fig. 13 Depth-structure map superimposed on maximum amplitude of horizon $T$

Funding This research work is self-funded.

\section{Compliance with ethical standards}

Conflicts of interest The authors declare that they have no conflict of interest.

Open Access This article is licensed under a Creative Commons Attribution 4.0 International License, which permits use, sharing, adaptation, distribution and reproduction in any medium or format, as long as you give appropriate credit to the original author(s) and the source, provide a link to the Creative Commons licence, and indicate if changes were made. The images or other third party material in this article are included in the article's Creative Commons licence, unless indicated otherwise in a credit line to the material. If material is not included in the article's Creative Commons licence and your intended use is not permitted by statutory regulation or exceeds the permitted use, you will need to obtain permission directly from the copyright holder. To view a copy of this licence, visit http://creativecommons.org/licenses/by/4.0/.

\section{References}

Adelu AO, Sanuade OA, Oboh EG, Offeh EO, Adewale T, Mumuni OS, Oladapo MI, Omolaiye EG (2016) Hydrocarbon field evaluation: case study of 'Tadelu'field shallow offshore Western Niger Delta, Nigeria. Arab J Geosci 9:116

Adeoti L, Igiri T, Adams L, Adekunle A, Bello MA (2014) Structural style and reservoir distribution in deep-water niger delta: a case study of "Nanny Field". Br J Appl Sci Technol 4:1375-1391

Akanji AO, Sanuade OA, Kaka SI, Balogun ID (2018) Integration of 3D seismic and well log data for the exploration of Kini Field, Offshore Niger Delta. Pet Coal 60:752-761

Anthony AA, Aurelius OO (2013) Reservoir characterization and structural interpretation of seismic profile: a case study of Z-field, Niger Delta, Nigeria. Pet Coal 55:37-43

Archie GE (1942) The electrical resistivity log as an aid in determining some reservoir characteristics. Pet Trans AIME 146:54-62

Asquith G, Krygowski D (2004) AAPG methods in exploration, No. 16: basic well log analysis, 2nd edn. The American Association of Petroleum Geologists 240-244 
Buller D, Kenyon W, Rasmus J, Miller S (1970) Evaluation porosity and producibility in clastics and oomoldic carbonate. Tech Rev 35:14-18

Busch DA (1975) Influence of growth faulting on sedimentation and prospect evaluation. Am Assoc Pet Geol Bull 59:414-419

Bustin RM (1988) Sedimentology and characteristics of dispersed organic matter in Tertiary Niger Delta: origin of source rocks in a deltaic environment. Am Asso Petrol Geol Bull 72:277-298

Catuneanu O (2006) Principles of sequence stratigraphy. Elsevier, Amsterdam

Chiazor FI, Beka FT (2019) Pore pressure prediction of an oil-field in part of the Niger Delta Basin, Nigeria. J Appl Sci Environ Manag 23:22673

Corredor F, Shaw JH, Bilotti F (2005) Structural styles in the deepwater fold and thrust belts of the Niger Delta. Am Asso Petrol Geol Bull 89:753-780

Dieokuma T, Gu HM, Liping W, Etim DU, Warmate T (2014) Petrophysical characteristics of coastal swamp depobelt reservoir in the Niger Delta using well-log data. IOSR J Appl Geol Geophys 2:76-85

Dim CIP, Onuoha KM, Mode AM, Okwara IC, Okeugo CG (2019) Characterizing the middle-upper miocene reservoir intervals of a producing field in the niger delta basin: an application of facies, sequence stratigraphic and petrophysical analyses. Arab J Sci Eng 44:429-448

Doust H, Omatsola M (1990) Petroleum geology of the Niger delta. Geol Soc Lond Spec Publ 50:365

Edigbue P, Olowokere MT, Adetokunbo P, Jegede E (2015) Integration of sequence stratigraphy and geostatistics in 3-D reservoir modeling: a case study of Otumara field, onshore Niger Delta. Arab J Geosci 8:8615-8631

Ejedawe J (1986) The expulsion criterion in the evaluation of the petroleum source beds of the tertiary Niger Delta. J Pet Geol 9:439-450

Emujakporue GO, Eyo AJ (2019) Structural and seismic sequence stratigraphy analysis of seismic and biostratigraphy data from an onshore field, Niger Delta, Nigeria. World News Nat Sci 22:190-199

Evamy BD, Haremboure J, Kamerling WA, Knaap P, Molley FA, Rowlands PH (1978) Hydrocarbon habitat of tertiary Niger Delta. Am Assoc Pet Geol Bull 62:1-39

Haack RC, Sundararaman P, Diedjomahor JO, Xiao H, Gant NJ, May ED, Kelsch K (2000) Niger delta petroleum systems, Nigeria. Am Assoc Petrol Geol Memoir 73:213-231

Hosper J (1971) The geology of the Niger Delta area, in the geology of the East Atlantic continental margin, Great Britain, Institute of Geological Science. Report 70:121-141

Ibe AA, Ezekiel OT (2018) Impact of structural setting on hydrocarbon trapping mechanism of onshore Niger Delta basin, Nigeria, using seismic attribute analysis. Egypt J Pet 27:1241-1249
Ibe AA, Ezekiel OT (2019) Hydrocarbon play assessment of X-field in an Onshore Niger Delta, Nigeria. J Pet Explor Prod Technol 9:61-74

Knox GJ, Omatsola EM (1989) Development of the cenozoic Niger Delta in terms of the "escalator regression" model and impact on hydrocarbon distribution of proceeding The KNGMG Symposium. Coastal Lowland Geology and Geotechnology 181-202

Koneshloo M, Aryana SA, Hu X (2018) The Impact of geological uncertainty on primary production from a fluvial reservoir. Pet Sci 15:270-288

Marfurt K, Chopra S (2007) Seismic Attributes for Prospect Identification and Reservoir Characterization, Stephen J. Hill. Tulsa, OK, USA

Okpogo EU, Abbey CP, Atueyi IO (2018) Reservoir characterization and volumetric estimation of Orok Field, Niger Delta hydrocarbon province. Egypt J Pet 27:1087-1094

Rider MH (1986) The geological interpretation of well logs, 1st edn. Halsted Press, New York, NY

Sanuade OA, Akanji AO, Olaojo AA, Oyeyemi KD (2018) Seismic interpretation and petrophysical evaluation of SH field, Niger Delta. J Pet Explor Prod Technol 8:51-60

Short KC, Stauble AJ (1967) Outline of geology of Niger Delta. Am Asso Petrol Geol Bull 51:761-779

Soneye TD, Osinowo OO (2019) Attribute analysis and structural modeling of $X$ field, Niger Delta, Southern Nigeria. Int J Eng Sci 8:70-77

Tanko A, Bello K, Tanko I (2019) Development of an appropriate model for predicting Pore Pressure in Niger delta, Nigeria using Offset Well Data. Int J Petrochem Res 3:274-279

Ukuedojor KO, Maju-Oyovwikowhe GE (2019) Reservoir geometry determination and volumetric reserve estimation of an Offshore, Niger Delta Basin Nigeria. J Geogr Environ Earth Sci Int 23:1-15

Umoren EB, Uko ED, Tamunobereton-ari I, Israel-Cookey C (2019) Pore pressure prediction in onshore west niger delta using inverted seismic velocity and derived velocity $(\mathrm{Vp})$ - vertical effective stress (VES) coefficients. J Environ Earth Sci 9:58-67

Weber KJ, Daukoru EM (1975) Petroleum geology of the Niger Delta. In: Proceedings of the 9th World Petroleum Congress. Applied Science Publishers, Ltd., London

Whiteman AJ (1982) Nigeria: Its Petroleum Geology: Resources and Potential.1 and 2. Graham and Trottan, London

Publisher's Note Springer Nature remains neutral with regard to jurisdictional claims in published maps and institutional affiliations. 